О.І. Слюсаренко ${ }^{1}$, О.М. Купріненко ${ }^{1}$, С.В. Кузнецов ${ }^{2}$

${ }^{1}$ Начіональна академія Сухопутних військ ім. П.Сагайдачного, Львів

${ }^{2}$ Національний університет оборони України ім. І. Черняховського, Київ

\title{
ВИЗНАЧЕННЯ ГРУП КОЛІСНИХ МАШИН СИЛ СПЕЦІАЛЬНИХ ОПЕРАЦІЙ ЗБРОЙНИХ СИЛ УКРАЇНИ ЗА ФУНКЦІОНАЛЬНИМИ ПОКАЗНИКАМИ МЕТОДАМИ КЛАСТЕРНОГО АНАЛІЗУ ЗАВДАНЬ
}

У статті проведено аналіз існуючих підходів формування парків колісних машин сил спеціальних операцій збройних сил провідних країн та основних світових тенденцій їх розвитку. Визначені основні функціональні показники колісних машин, які впливають на повноту і якість виконання завдань підрозділами Сил спеціальних операцій Збройних Сил Украӥни. Розглянуто проблеми розробки номенклатури колісних машин для потреб Сил спеціальних операчій Збройних Сил Украӥни відповідно до специфіки покладених на них завдань. За результатами проведеного аналізу сукупності завдань, які покладаються на Сили спеціальних операцій Збройних Сил Украӥни, визначені основні дії підрозділів Сил спеціальних операцій та вимоги до функиіональних показників колісних машин. Широка різноманітність варіантів застосування підрозділів Сил спеціальних операџій та вимог до колісних машин обумовлює необхідність систематизації завдань за функціональними показниками колісних машин. Кластерний аналіз значень оцінок експертів в галузі застосування підрозділів Сил спеціальних операцій Збройних Сил Украӥни дозволив визначити класи колісних машин, необхідних для вирішення повного спектру завдань Сил спецііальних операцій Збройних Сил Украӥни.

Ключові слова: сили спеціальних операцій, завдання, колісні машини, кластерний аналіз, номенклатура, функціональні показники.

\section{Вступ}

Постановка проблеми. Наприкінці XX - на початку XXI ст. спостерігається різке зростання збройних протистоянь, у яких керівництво збройних сил багатьох країн зіткнулося з необхідністю брати участь у бойових діях проти іррегулярних озброєних формувань. Вміле використання іррегулярними формуваннями асиметричних способів ведення збройної боротьби й окремих функціональних недоліків звичайних збройних сил, розосереджені дії на знайомій місцевості, уникнення класичних способів ведення збройної боротьби та прямих зіткнень робить застосування звичайних збройних сил малоефективним. Необхідність протидії новим загрозам та викликам призвела до появи у складі збройних сил багатьох провідних країн нової окремої компоненти - сил спеціальних операцій (ССпО), які здатні адекватно реагувати на нові виклики і загрози національній та міжнародній безпеці не тільки у військовий, але і в мирний час, як за кордоном так і на власній території [1-2].

Основними відмінностями дій ССпО від інших силових структур є застосування спеціальних і специфічних методів та способів дій, підвищені вимоги до прихованості (скритності), автономності й інших факторів, високий ступінь фізичного та політичного ризику під час дій у незнайомому, ворожому середовищі або політично нестабільній обстановці, які можуть мати політичні, воєнні, дипломатичні, інформаційні або економічні наслідки.

Аналіз військових конфліктів останніх десятиліть свідчить про різке зростання впливу засобів збройної боротьби, а саме, озброєння та військової техніки, на характер і ефективність ведення бойових дій підрозділами ССпО, а їх напрям розвитку впливає на форми та способи ведення підрозділами ССпО збройної і незбройної боротьби [3].

За таких обставин ССпО повинні оснащуватись сучасними високотехнологічними зразками військової техніки, які максимально відповідають вирішенню широкого спектру спеціальних завдань та є невластивими (нехарактерними) для інших видів (родів) військ (сил), спеціальних військ Збройних Сил (3С) України [4-5]. Різноманітність і неоднорідність завдань та умов їх виконання, необхідність забезпечення високої рухомості підрозділів ССпО вимагають наявності в їх складі широкої номенклатури різних за типом та конструкцією колісних машин (КМ), які повинні максимально враховувати специфіку покладених на них завдань.

Аналіз останніх досліджень і публікацій. На сьогодні у світі сформована широка номенклатура КМ ССпО, які відрізняються призначенням, конструктивними рішеннями, тактико-технічними характеристиками (ТTX) та вартістю [6-11]. Основними причинами різноманіття КМ ССпО є: 
- відмінності у поглядах країн на роль, місце та завдання ССпО у розв'язанні протиріч та воєнних конфліктів;

- воєнно-політична обстановка у світі та навколо країни, їі воєнна доктрина;

- ймовірність участі країни у воєннополітичних протистояннях і військових конфліктах;

- стан наявного парку КМ ССпО країни;

- військове партнерство, науково-технічні та виробничо-економічні можливості тощо.

Зростання ролі ССпО у вирішенні сучасних військових конфліктів низької інтенсивності обумовлює необхідність у постійному удосконаленні та оновленні існуючого парку КМ. За рахунок належного фінансування з боку держави, інвестиційних i власних фондів, високого науково-технічного та виробничого потенціалу КМ ССпО провідних країн світу постійно удосконалюється й оновлюється 3 урахуванням тенденцій розвитку збройної боротьби та максимально використовуючи досягнення в галузі розробки й експлуатації транспортних засобів. Вивчення світового досвіду створення номенклатури КМ для ССпО свідчить про існування трьох основних підходів до розробки та модернізації КМ [12-13].

Перший (класичний) підхід грунтується на максимальному залученні серійних цивільних зразків у якості базових. За таких умов значно зменшуються витрати на розробку, модернізацію, навчання водіїв та логістичне супроводження військових зразків КМ, максимально застосовуються сучасні технічні рішення.

Другий підхід базується на створенні сімейства КМ, які максимально пристосовані для вирішення, у першу чергу, військових завдань. Водночас, конструкція вищезазначених КМ, застосування принципу модульності та оптимальне поєднання споживчих якостей дозволяє застосовувати дані КМ у різних галузях господарства (національної економіки).

Третій підхід притаманний країнам з високим науково-технічним, промисловим i економічним потенціалом та грунтується на створенні зразків суто воєнного призначення для вирішення конкретних військових завдань. 3 точки зору військових фахівців даний підхід $\epsilon$ максимально ефективним і раціональним, але значно збільшується номенклатура КМ та ускладняється їх логістичне супроводження.

Складності, які виникають під час створення номенклатури КМ ССпО Збройних Сил (ЗС) України обумовлюються:

- незавершеністю формування поглядів на склад та завдання ССпО ЗС України, способи їх застосування;

- браком досвіду бойового застосування в іррегулярних конфліктах та у складі коаліційних і між- народних сил в антитерористичних та міжнародних операціях з підтримання миру і безпеки;

- низькими тактико-технічними та експлуатаційними характеристиками більшості парку КМ, основу якого складають зразки радянського виробництва;

- виробничо-економічними чинниками, недостатньою ефективністю воєнно-наукових обгрунтувань, тощо.

За таких умов необхідність забезпечення ССпО ЗС України КМ, специфічність вирішуємих ними завдань, різнотипність підходів щодо створення і модернізації існуючих зразків КМ, їх широка номенклатура у світі з одного боку, та обмежені економічні та виробничі можливості України з іншого, дозволяють стверджувати, що для ССпО ЗС України доцільно мати раціональний склад номенклатури КМ, систематизованих та уніфікованих за функціонально-конструктивними ознаками i значеннями параметрів, що забезпечують перспективну потребу ССпО у КМ та максимально враховують специфіку покладених на них завдань.

Мета статті - проведення відповідного аналізу завдань, які фактично вирішуються ССпО за допомогою КМ, з метою визначення вимог до властивостей КМ та зв'язку між ними для подальшого обгрунтування технічних параметрів КМ ССпО в залежності від покладених на них завдань.

\section{Виклад основного матеріалу}

Аналіз літературних джерел свідчить, що кожна країна шукає власні шляхи для забезпечення відповідності номенклатури озброєння та іншої військової техніки сучасним викликам і загрозам [3;9]. Водночас на загальносвітовому рівні або на рівні передових у військовому відношенні країн чітко прослідковуються основні тенденції розвитку КМ ССпО (рис. 1). Врахування ЗС України та державою в цілому загальних тенденцій розвитку КМ ССпО має важливе значення для мінімізації ресурсних та часових витрат під час розробки, виготовлення нових зразків КМ, модернізації та оновлення існуючого парку КМ ССпО ЗС України.

Послідовність проведення обгрунтування номенклатури КМ ССпО ЗС України передбачає:

1) Визначення переліку завдань, які покладаються на підрозділи ССпО.

2) Декомпозицію завдань, які покладаються на підрозділи ССпО.

3) Кластерний аналіз дій, які виконують підрозділи ССпО із застосуванням КМ.

4) Визначення зразків КМ для виконання завдань підрозділами ССпО

5) Визначення переліку параметрів для побудови номенклатури КМ та їх значень.

6) Побудова вихідного типорозмірного ряду. 
7) Моделювання процесу бойового застосування КМ ССпО.

8) Побудова раціонального типорозмірного
9) Розробка пропозицій щодо формування варіантів номенклатури КМ ССпО. ряду.

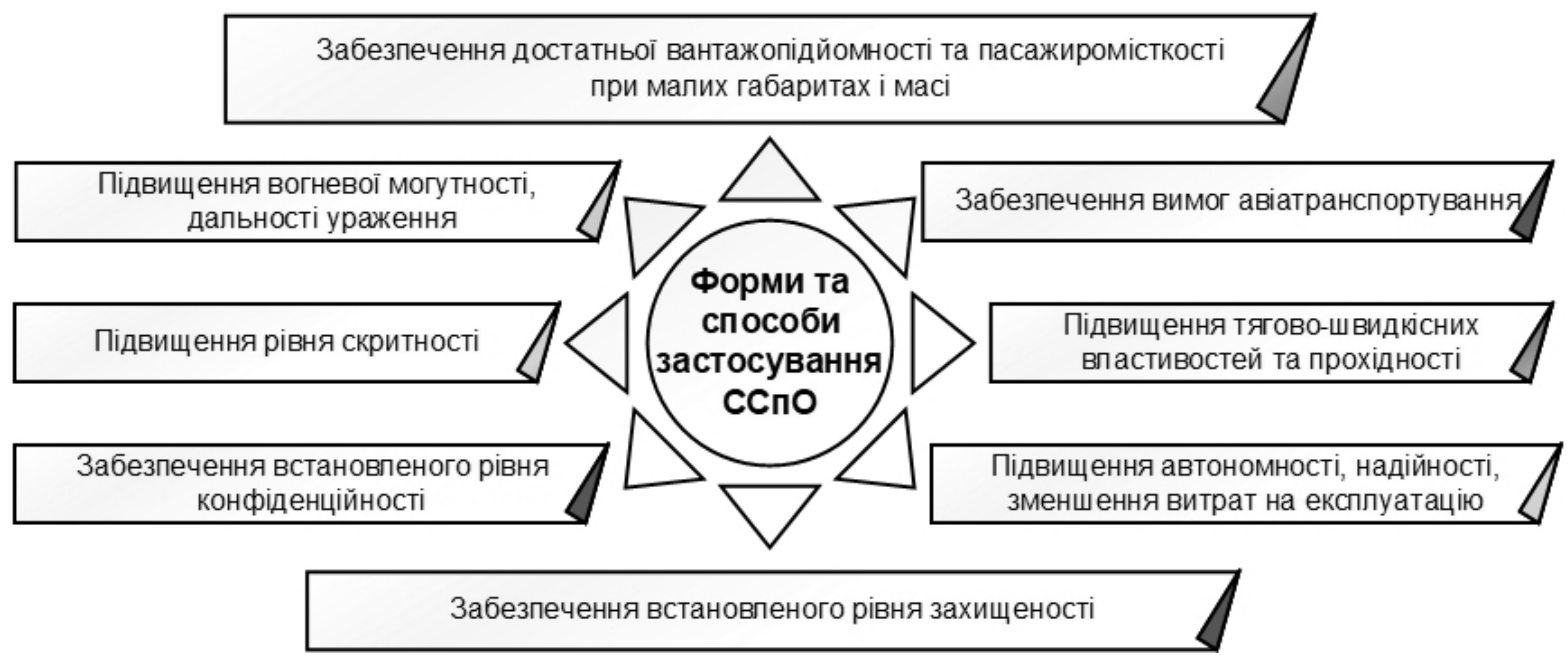

Рис. 1. Основні світові тенденції розвитку КМ ССпО

Вихідними даними для виконання перших трьох етапів є завдання ССпО ЗС України, відповідно до яких визначається місце і роль у них КМ, та основні властивості КМ, які впливають на ефективність виконання завдань підрозділами ССпО. Формування сукупності завдань, які покладаються на підрозділи ССпО 3С України, здійснюється на основі детального аналізу нормативно-правових документів щодо форм, способів та умов бойового застосування підрозділів ССпО, вивчення світового і власного досвіду участі ССпО у бойових діях різної інтенсивності та на різних етапах розвитку конфліктів.
В ході другого етапу проводиться декомпозиція сукупності завдань підрозділів ССПО як складної системи застосування ССпО. Ця декомпозиція виконується у декілька кроків. На першому кроці відповідно до цілей ССпО визначаються основні форми застосування, які в сукупності забезпечують виконання всіх цілей ССпО. На наступних кроках форми застосування розбивають на окремі завдання, завдання - на підзавдання і окремі дії. У результаті одержують ієрархічне дерево завдань ССпО (рис. 2).

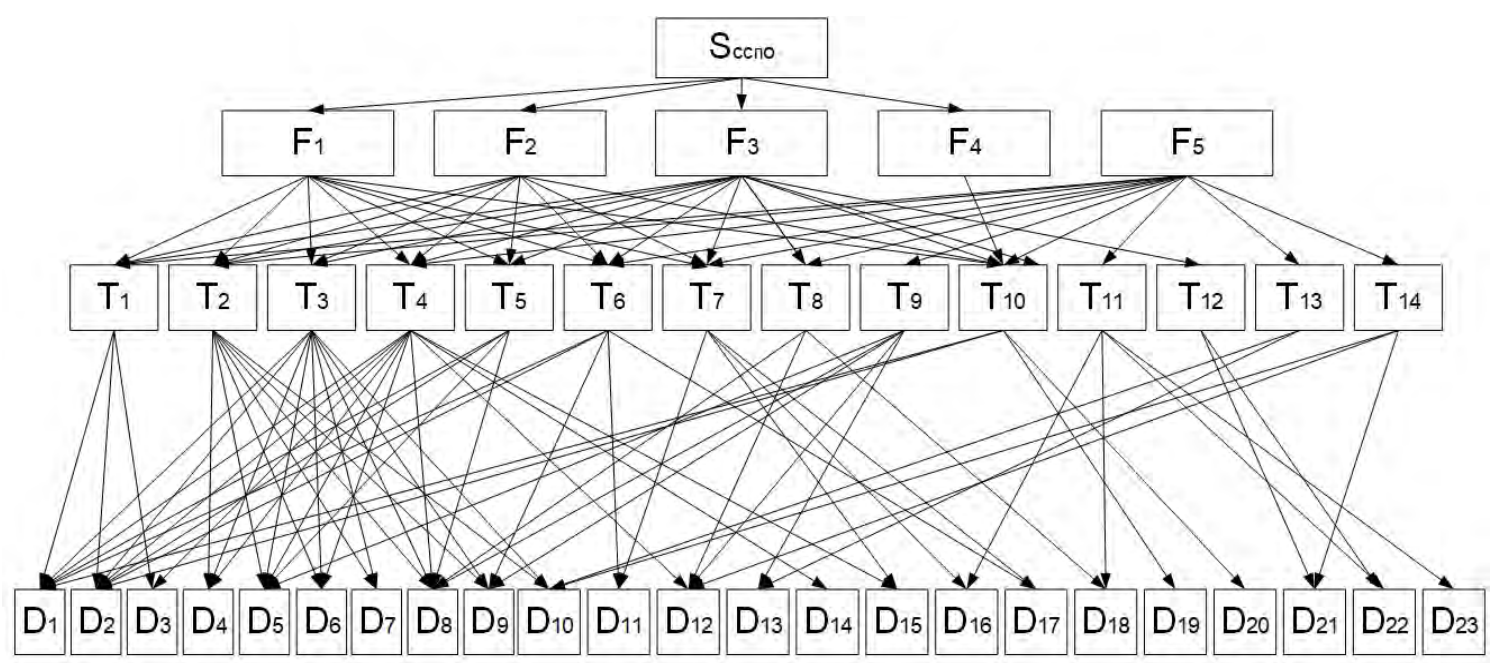

$F_{1-5}$ - форми застосування ССпО ЗС України;

Т1-14 - завдання, які покладаються на підрозділи ССпО ЗС України;

D1-23 - дії, які виконуються підрозділами CCпО 3С України за участю КМ.

Рис. 2. Декомпозиція сукупності завдань ССпО 3С України 
Велика сукупність можливих варіантів застосування КМ у діях підрозділів ССпО з врахуванням особливостей умов застосування обумовлює необхідність проведення їх групування за функціональними ознаками КМ для подальшого визначення загального вигляду необхідних зразків КМ та забезпечення максимальної відповідності їх характеристик функціональному призначенню.

Водночас процес визначення переліку та наближених значень основних властивостей КМ, які $\epsilon$ важливими під час виконання підрозділами ССпО своїх дій, супроводжується невизначеністю і неповнотою інформації внаслідок браку (відсутності) знань про вплив даних властивостей на ефективність виконання завдань ССпО, неможливістю або обмеженою можливістю експериментального дослідження цих процесів тощо. За таких умов процес дослідження 3 використанням традиційних методів теорії ймовірності та статистики моделювання є малоефективним і потребує інших підходів, які передбачають використання досвіду фахівців [14-15]. Проведене опитування 24 експертів в галузі застосування підрозділів ССпО з використанням послідо- вної інтерактивної процедури, яка грунтується на почерговому включенні все нових експертів до моменту стабілізації їх оцінок, дозволило визначити перелік основних вимог до КМ ССпО, встановити зв'язок між діями підрозділів ССпО ЗС України 3 урахуванням умов застосування і основними функціональними показниками та визначити їх наближені значення [16-18]. До основних функціональних показників КМ ССпО, які впливають на повноту та ефективність виконання завдань, експерти зазначили пасажиромісткість, вантажопідйомність, авіатранспортабельність, вогнева могутність, захищеність, середня швидкість, прохідність, скритність, конфіденційність, запас ходу по пальному. Складність процесу подальшої класифікації дій ССпО по вимогам до КМ полягає в їх багатомірності, коли кожна дія висуває вимогу по кожному 3 десятьох функціональних показників, а окремі вимоги носять якісний характер. Тому, встановлення значень функціональних показників КМ для кожного варіанту застосування проведено за бальною системою, наведеною у таблиці (табл. 1).

Таблиця оцінювання функціональних показників КМ ССпО

\begin{tabular}{|c|c|c|c|c|c|c|c|c|c|c|}
\hline $\begin{array}{l}\text { Оцінка } \\
\text { (бали) }\end{array}$ & 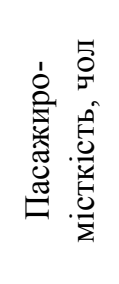 &  & 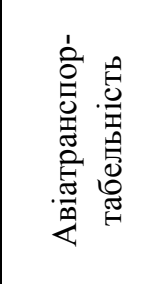 & 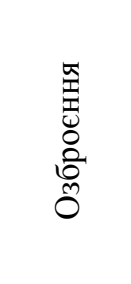 & 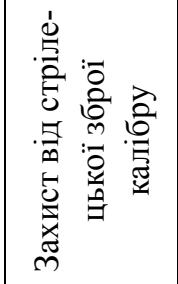 &  &  & 兽 & 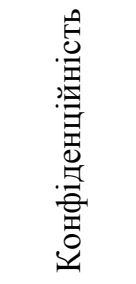 & 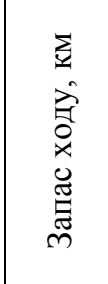 \\
\hline 1 & $\begin{array}{c}\text { до } \\
2\end{array}$ & $\begin{array}{c}\text { не } \\
\text { висуваються }\end{array}$ & $\begin{array}{c}\text { внутріш- } \\
\text { ній відсік } \\
\text { гелікопте- } \\
\text { ра } \\
\end{array}$ & $\begin{array}{c}\text { не } \\
\text { висува- } \\
\text { ються }\end{array}$ & $\begin{array}{l}\text { не вису- } \\
\text { ваються }\end{array}$ & висока & висока & висока & висока & до 200 \\
\hline 2 & $\begin{array}{c}\text { до } \\
4\end{array}$ & $\begin{array}{c}\text { до } \\
200\end{array}$ & $\begin{array}{c}\text { зовнішня } \\
\text { підвіска } \\
\text { гелікопте- } \\
\text { ра } \\
\end{array}$ & 7,62 мм & до 7,62мм & $\begin{array}{l}\text { підви- } \\
\text { щена }\end{array}$ & $\begin{array}{l}\text { підви- } \\
\text { щена }\end{array}$ & $\begin{array}{l}\text { підви- } \\
\text { щена }\end{array}$ & $\begin{array}{c}\text { підви- } \\
\text { щена }\end{array}$ & до 400 \\
\hline 3 & $\begin{array}{c}\text { до } \\
8\end{array}$ & $\begin{array}{c}\text { до } \\
500\end{array}$ & $\begin{array}{c}\text { внутріш- } \\
\text { ній відсік } \\
\text { літака }\end{array}$ & $12,7 \mathrm{MM}$ & до $12,7 \mathrm{мм}$ & $\begin{array}{l}\text { не ви- } \\
\text { сува- } \\
\text { ються }\end{array}$ & $\begin{array}{l}\text { не вису- } \\
\text { ваються }\end{array}$ & $\begin{array}{l}\text { не ви- } \\
\text { сува- } \\
\text { ються }\end{array}$ & $\begin{array}{l}\text { не вису- } \\
\text { ваються }\end{array}$ & до 600 \\
\hline 4 & $\begin{array}{l}\text { до } \\
10\end{array}$ & $\begin{array}{c}\text { до } \\
1000\end{array}$ & - & $14,5 \mathrm{MM}$ & $\begin{array}{l}\text { до 14,5мм, } \\
\text { протимін- } \\
\text { ний захист }\end{array}$ & - & - & - & - & $\begin{array}{c}\text { більше } \\
600\end{array}$ \\
\hline 5 & $\begin{array}{c}\text { більше } \\
10\end{array}$ & $\begin{array}{c}\text { до } \\
2500\end{array}$ & - & $\begin{array}{l}\text { більше } \\
\text { 14,5 мм }\end{array}$ & $\begin{array}{c}\text { більше } \\
\text { 14,5мм, } \\
\text { протимін- } \\
\text { ний захист }\end{array}$ & - & - & - & - & - \\
\hline 6 & - & $\begin{array}{c}\text { до } \\
5000\end{array}$ & - & - & - & - & - & - & - & - \\
\hline
\end{tabular}

Єдине упорядковане та формалізоване узагальнення інформації надає класифікація [16-19]. Кла- сифікацію дій підрозділів ССпО ЗС України здійснено з використанням методів кластерного аналізу, 
які дозволяють об'єднати дії у групи з максимальною подібністю вимог до функціональних ознак КМ та суттєвими відмінностями між групами. Вихідними даними для проведення аналізу слугують визначені експертами вимоги до функціональних ознак КМ під час виконання дій підрозділами ССпО (табл. 2). На першому етапі проведено аналіз даних методом послідовної кластеризації, в результаті такого аналізу, в залежності від обраного алгоритму обробки матриці даних, отримано дендрограму, що однозначно описує матрицю відстаней між елементами. Якщо $X=\left\{x_{1}, \ldots, x_{n}\right\}$ множина $n$ об'єктів, кожен 3 яких характеризується $m$ ознаками, то кожен з об'єктів може розглядатися як точка в $m$-мірному простоpi. Тоді вхідні дані можуть бути представлені матрицею

$$
X=\left(\begin{array}{cccc}
x_{1}^{1} & x_{1}^{2} & \ldots & x_{1}^{m} \\
x_{2}^{1} & x_{2}^{2} & \ldots & x_{2}^{m} \\
\ldots & \ldots & \ldots & \ldots \\
x_{n}^{1} & x_{n}^{1} & \ldots & x_{n}^{m}
\end{array}\right)
$$

де $x_{j}^{i}$-значення $i$-ої ознаки $j$-ого об'єкту. Таким чином, $i$-й рядок цієї матриці повністю характеризує зразок $x_{i}$ та інтерпретується як точка в $m$-мірному просторі $I^{m}(X)$.
Близькості між об'єктами множини X можуть бути представлені у формі матриці:

$$
D=\left(\begin{array}{cccc}
0 & d_{12} & \ldots & d_{1 n} \\
d_{21} & 0 & \ldots & d_{2 n} \\
\ldots & \ldots & \ldots & \ldots \\
d_{n 1} & d_{n 2} & \ldots & 0
\end{array}\right),
$$

де $d_{i j}$ - близькість зразків $x_{i}$ та $x_{j}$ один від одного.

Як характеристики близькості використаємо евклідову метрику:

$$
d_{i j}=\left(\sum_{l=1}^{m}\left(x_{i}^{l}-x_{j}^{l}\right)^{2}\right)^{\frac{1}{2}} .
$$

Для побудови дендрограми використано програмний продукт Statistica 12 [20]. Перед початком аналізу проведено стандартизацію змінних згідно 3 виразом

$$
x_{i}^{s t}=\left(x_{i}-\bar{x}\right) /\left((n-1)^{-1} \sum_{n}\left[\bar{x}-x_{i}\right]^{2}\right),
$$

де $\bar{x}=n^{-1} \sum_{n} x_{n},-$ середнє значення ознаки, що дало можливість усунути зміщення, викликане впливом тих ознак, які мають більший розмах значень. Як правило об'єднання використано метод повних зв'язків, відповідно до якого схожість між кандидатами на включення в існуючий кластер і будь-яким iз його елементів має бути меншою деякого порогового рівня, який визначає діаметр підмножини.

Результати аналізу наведені на рис. 3

\begin{tabular}{|c|c|c|c|c|c|c|c|c|c|c|}
\hline \multirow[b]{2}{*}{ 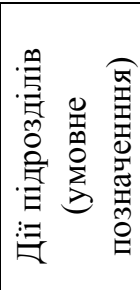 } & \multicolumn{10}{|c|}{ Функціональні показники КМ } \\
\hline & 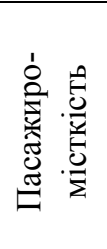 & 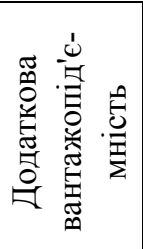 & 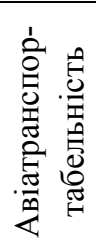 & 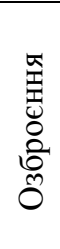 &  & 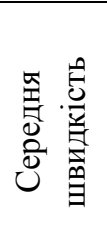 & 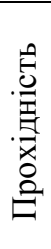 &  & 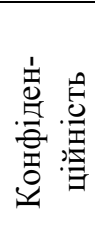 & 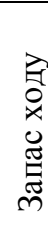 \\
\hline 1 & 2 & 3 & 4 & 5 & 6 & 7 & 8 & 9 & 10 & 11 \\
\hline 1.1 & 1 & 1 & 1 & 1 & 1 & 1 & 1 & 1 & 2 & 1 \\
\hline 1.2 & 2 & 1 & 1 & 1 & 1 & 1 & 1 & 2 & 1 & 3 \\
\hline 1.3 & 2 & 1 & 1 & 1 & 2 & 1 & 1 & 2 & 1 & 3 \\
\hline 2.1 & 2 & 2 & 1 & 1 & 1 & 1 & 1 & 1 & 2 & 1 \\
\hline 2.2 & 1 & 2 & 1 & 1 & 1 & 1 & 1 & 2 & 1 & 3 \\
\hline 2.3 & 1 & 2 & 1 & 1 & 2 & 1 & 1 & 2 & 1 & 3 \\
\hline 3.1 & 2 & 2 & 1 & 1 & 2 & 1 & 1 & 1 & 2 & 1 \\
\hline 3.2 & 2 & 2 & 1 & 1 & 2 & 1 & 1 & 2 & 1 & 3 \\
\hline 4.1 & 1 & 1 & 1 & 1 & 1 & 1 & 1 & 1 & 2 & 1 \\
\hline 4.2 & 1 & 1 & 1 & 1 & 1 & 1 & 1 & 2 & 1 & 3 \\
\hline \begin{tabular}{|l|}
4.3 \\
\end{tabular} & 1 & 1 & 1 & 1 & 2 & 1 & 1 & 2 & 1 & 3 \\
\hline 5.1 & 2 & 3 & 1 & 2 & 2 & 1 & 1 & 1 & 2 & 1 \\
\hline \begin{tabular}{|l|}
5.2 \\
\end{tabular} & 3 & 4 & 2 & 3 & 3 & 2 & 2 & 2 & 2 & 3 \\
\hline
\end{tabular}

Таблиця 2

Експертні оцінки функціональних показників

КМ ССпO 
Продовження табл. 2

\begin{tabular}{|c|c|c|c|c|c|c|c|c|c|c|}
\hline 1 & 2 & 3 & 4 & 5 & 6 & 7 & 8 & 9 & 10 & 11 \\
\hline 5.3 & 4 & 4 & 3 & 3 & 4 & 2 & 2 & 2 & 3 & 3 \\
\hline 5.4 & 2 & 4 & 1 & 3 & 2 & 1 & 1 & 2 & 1 & 3 \\
\hline 6.1 & 2 & 3 & 1 & 2 & 2 & 1 & 1 & 1 & 2 & 1 \\
\hline 6.2 & 3 & 4 & 1 & 2 & 2 & 1 & 1 & 2 & 2 & 3 \\
\hline 6.3 & 3 & 4 & 2 & 3 & 3 & 2 & 2 & 2 & 2 & 3 \\
\hline 6.4 & 2 & 4 & 1 & 3 & 2 & 1 & 1 & 2 & 1 & 3 \\
\hline 7.1 & 3 & 4 & 1 & 3 & 2 & 1 & 1 & 2 & 2 & 3 \\
\hline 7.2 & 3 & 4 & 2 & 3 & 3 & 2 & 2 & 2 & 2 & 3 \\
\hline $\begin{array}{l}7.3 \\
\end{array}$ & 2 & 4 & 1 & 3 & 2 & 1 & 1 & 2 & 1 & 3 \\
\hline 8.1 & 3 & 4 & 1 & 2 & 3 & 1 & 1 & 2 & 2 & 3 \\
\hline 8.2 & 3 & 4 & 2 & 3 & 3 & 2 & 2 & 2 & 2 & 3 \\
\hline 8.3 & 2 & 3 & 1 & 1 & 1 & 1 & 1 & 2 & 1 & 3 \\
\hline 8.4 & 2 & 4 & 1 & 3 & 2 & 1 & 1 & 2 & 1 & 3 \\
\hline 9.1 & 3 & 5 & 1 & 2 & 2 & 1 & 1 & 2 & 2 & 3 \\
\hline 9.2 & 3 & 5 & 2 & 3 & 3 & 2 & 2 & 2 & 2 & 3 \\
\hline 9.3 & 4 & 5 & 3 & 3 & 4 & 2 & 2 & 2 & 3 & 3 \\
\hline 9.4 & 3 & 4 & 1 & 2 & 2 & 1 & 1 & 2 & 1 & 3 \\
\hline 10.1 & 2 & 3 & 1 & 1 & 1 & 1 & 1 & 1 & 2 & 1 \\
\hline 10.2 & 2 & 3 & 1 & 1 & 1 & 1 & 1 & 2 & 1 & 3 \\
\hline 10.3 & 2 & 3 & 1 & 1 & 2 & 1 & 1 & 2 & 1 & 3 \\
\hline 11.1 & 2 & 3 & 1 & 2 & 2 & 1 & 1 & 1 & 2 & 1 \\
\hline 11.2 & 3 & 4 & 1 & 2 & 2 & 1 & 1 & 2 & 2 & 3 \\
\hline 11.3 & 2 & 3 & 1 & 1 & 1 & 1 & 1 & 2 & 1 & 3 \\
\hline 11.4 & 2 & 3 & 1 & 2 & 2 & 1 & 1 & 2 & 1 & 3 \\
\hline 12.1 & 3 & 4 & 2 & 3 & 3 & 2 & 2 & 2 & 2 & 3 \\
\hline 12.2 & 4 & 4 & 3 & 3 & 4 & 2 & 2 & 2 & 3 & 3 \\
\hline 12.3 & 2 & 4 & 1 & 3 & 3 & 1 & 1 & 2 & 1 & 3 \\
\hline 13.1 & 3 & 3 & 1 & 2 & 3 & 1 & 1 & 2 & 2 & 3 \\
\hline 13.2 & 4 & 5 & 3 & 3 & 4 & 2 & 2 & 2 & 3 & 3 \\
\hline 13.3 & 2 & 3 & 1 & 1 & 1 & 1 & 1 & 2 & 1 & 3 \\
\hline 13.4 & 2 & 4 & 1 & 2 & 2 & 1 & 1 & 2 & 1 & 3 \\
\hline 14.1 & 3 & 5 & 2 & 3 & 3 & 2 & 2 & 2 & 2 & 3 \\
\hline 14.2 & 4 & 5 & 3 & 3 & 4 & 2 & 2 & 2 & 3 & 3 \\
\hline 14.3 & 2 & 4 & 1 & 3 & 2 & 1 & 1 & 2 & 1 & 3 \\
\hline 15.1 & 2 & 2 & 1 & 1 & 1 & 1 & 1 & 1 & 2 & 1 \\
\hline 15.2 & 3 & 4 & 1 & 2 & 2 & 1 & 1 & 2 & 2 & 3 \\
\hline 15.3 & 2 & 3 & 1 & 2 & 2 & 1 & 1 & 2 & 1 & 3 \\
\hline 16.1 & 3 & 4 & 2 & 3 & 3 & 2 & 2 & 2 & 2 & 3 \\
\hline 16.2 & 4 & 5 & 3 & 3 & 4 & 2 & 2 & 2 & 3 & 3 \\
\hline 16.3 & 3 & 4 & 1 & 3 & 3 & 1 & 1 & 2 & 1 & 3 \\
\hline $\begin{array}{ll}17.1 \\
\end{array}$ & 5 & 6 & 3 & 3 & 5 & 3 & 2 & 2 & 3 & 3 \\
\hline 17.2 & 3 & 4 & 1 & 1 & 3 & 1 & 1 & 2 & 1 & 3 \\
\hline 18.1 & 2 & 2 & 1 & 2 & 2 & 1 & 1 & 1 & 2 & 1 \\
\hline 18.2 & 3 & 3 & 1 & 2 & 3 & 1 & 1 & 2 & 2 & 3 \\
\hline 18.3 & 2 & 3 & 1 & 2 & 3 & 1 & 1 & 2 & 1 & 3 \\
\hline 19.1 & 3 & 4 & 1 & 2 & 2 & 1 & 1 & 2 & 2 & 3 \\
\hline 19.2 & 2 & 3 & 1 & 1 & 1 & 1 & 1 & 2 & 1 & 3 \\
\hline 19.3 & 2 & 3 & 1 & 1 & 2 & 1 & 1 & 2 & 1 & 3 \\
\hline 20.1 & 3 & 4 & 1 & 2 & 2 & 1 & 1 & 2 & 2 & 3 \\
\hline 20.2 & 2 & 3 & 1 & 1 & 1 & 1 & 1 & 2 & 1 & 3 \\
\hline 20.3 & 2 & 3 & 1 & 1 & 2 & 1 & 1 & 2 & 1 & 3 \\
\hline 21.1 & 2 & 3 & 1 & 1 & 2 & 1 & 1 & 1 & 2 & 1 \\
\hline 21.2 & 3 & 4 & 1 & 2 & 2 & 1 & 1 & 2 & 2 & 3 \\
\hline 21.3 & 2 & 3 & 1 & 1 & 2 & 1 & 1 & 2 & 1 & 3 \\
\hline
\end{tabular}


Закінчення табл. 2

\begin{tabular}{|l|l|l|l|l|l|l|l|l|c|c|}
\hline 22.1 & 2 & 3 & 1 & 1 & 2 & 1 & 1 & 1 & 2 & 1 \\
\hline 22.2 & 3 & 4 & 1 & 2 & 2 & 1 & 1 & 2 & 2 & 3 \\
\hline 22.3 & 2 & 3 & 1 & 1 & 2 & 1 & 1 & 2 & 1 & 3 \\
\hline 23.1 & 2 & 3 & 1 & 1 & 2 & 1 & 1 & 1 & 2 & 1 \\
\hline 23.2 & 3 & 4 & 1 & 2 & 2 & 1 & 1 & 2 & 2 & 3 \\
\hline 23.3 & 2 & 3 & 1 & 1 & 2 & 1 & 1 & 2 & 1 & 3 \\
\hline
\end{tabular}

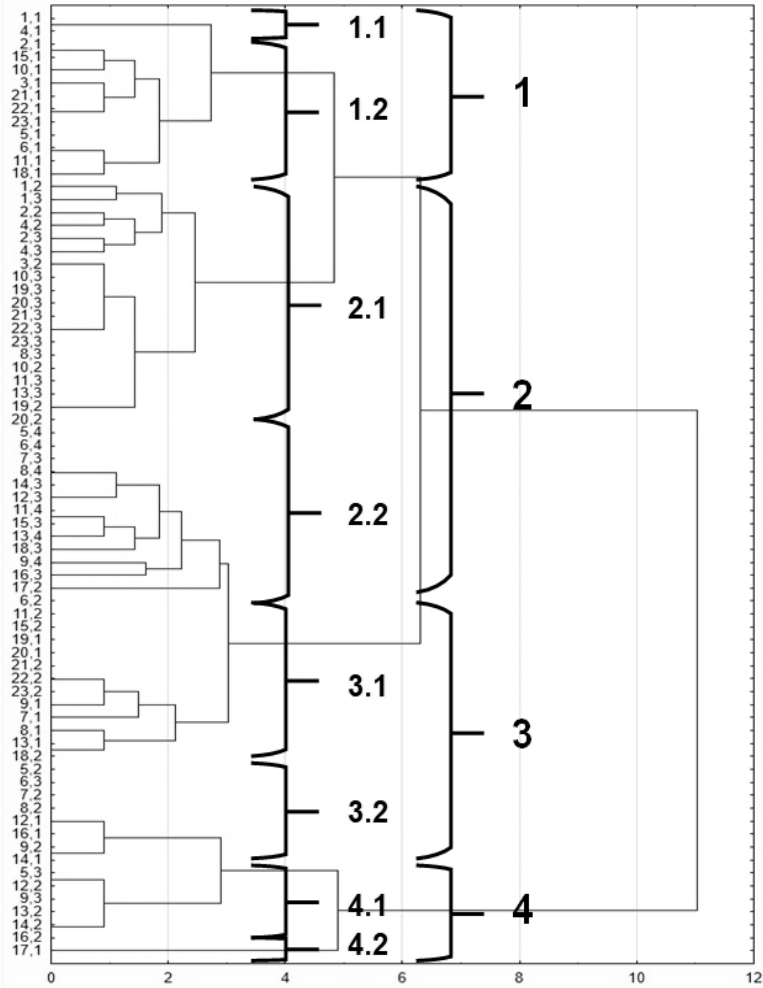

Рис. 3. Дендрограма даних, наведених у табл. 2.

Метод повних зв’язків

Аналіз дендрограми, побудованої на основі експертних оцінок вимог до КМ ССпО відповідно до їх застосування за допомогою ієрархічних агломеративних методів, свідчить на наявність чіткої структури. Сукупність дій ССпО 1.1-2.1 характеризується потребою у легких малогабаритних КМ 3 малою вантажопідйомністю та високими показниками рухомості, прохідності і скритності, здатністю до авіатранспортування у внутрішньому відсіку гелікоптера. Для окремих дій присутні вимоги до встановлення додаткового захисту та озброєння. Сукупність 2.2-3.1 характеризується потребою у КМ 3 середньою пасажиромісткістю і вантажопідйомністю, високими показниками рухомості, прохідності і скритності, здатністю до авіатранспортування переважно на зовнішній підвісці гелікоптера, наявність броньового захисту та озброєння розглядається переважно як базовий. Сукупності 3.2-4.2 характеризуються високими вимогами до пасажиромісткості, вантажопідйомності та вогневої могутності КМ, а 4.1 та 4.2 додатково - до балістичного та протимінного захисту. Об'єднання окремих сукупностей вимог дозволяє обгрунтувати технічний вигляд перспективних КМ для ССпО. Вимоги 1.1 i 1.2 найбільш характерні КМ сімейства спеціальних ударних автомобілів, 3.1 і 3.2 - тактичним КМ легкої та середньої категорії, 4.1 і 4.2 - легким та середнім КM типу MRAP. Характерною рисою сукупностей 2.1 та 2.2 є підвищені вимоги до конфіденційності, тому для даних дій в якості базових КМ доцільно розглядати комерційні автомобілі як базової, так і спеціальної комплектації, в тому числі, і на місцевій реєстрації. Для скорочення різнотипності та досягнення належного рівня уніфікації для кожного сімейства КМ доцільно мати один базовий зразок, а модифікації створювати з врахуванням вимог до необхідного рівня вогневої могутності, вантажопідйомності, пасажиромісткості, балістичного і протимінного захисту.

Базовий зразок повинен забезпечувати максимальну можливість уніфікації з модифікаціями, високі технічні і експлуатаційні показники, мінімальні часові та фінансові витрати для проведення модернізації, модульність тощо. Для обгрунтування значень основних і головних параметрів даних КМ доцільно проведення додаткових наукових досліджень.

\section{Висновки}

1. Широка різноманітність варіантів застосування підрозділів Сил спеціальних операцій та вимог до колісних машин обумовлює необхідність систематизації завдань за функціональними показниками колісних машин.

2. За результатами опитування фахівців в галузі застосування підрозділів ССпО сформовано вимоги до функціональних показників КМ в залежності від завдань, які фактично ними вирішуються. Застосування методів кластерного аналізу дозволило визначити групи колісних машин, необхідних для виконання завдань ССпО.

\section{Список літератури}

1. Воробйов Г.П. Розвиток форм і способів застосування Збройних Сил України / Г.П. Воробйов // Наука і оборона. - 2014. - № 1. - С. 27-30. 
2. Указ Президента України. "Про нову редакцію Воєнної доктрини України” № 555/2015 від 24 вересня 2015” [Електронний ресурс]. - Режим доступу: https://zakon.rada.gov.ua/laws/show/555/2015.

3. Чепков І.Б. Загальні тенденції розвитку озброєння та військової техніки / І.Б. Чепков, П.І Нор // Озброєння та військова техніка. - 2014. - № 1. - С. 4-13. https://doi.org/10.34169/2414-0651.2014.1(1).4-13.

4. Слюсаренко А.В. Досвід створення та структура сил спеціальних операцій провідних країн світу. / А.В. Слюсаренко // Військово-науковий вісник. - 2017. - № 29. - С.170-181. https://doi.org/10.33577/23135603.29.2018.170-181.

5. Луценко А.С. Аналіз досвіду створення, тенденцій розвитку та особливостей підготовки сил спеціальних операцій / А.С. Луценко // Системи озброєння і військова техніка. - 2010. - № 1(21). - С. 27-30.

6. Проблеми технічного оснащення Збройних Сил України та шляхи їх розв'язання в сучасних умовах / І.Б. Чепков, І.В. Борохвостов, В.К. Борохвостов, А.О. Русевич // Наука і оборона. - 2014. - № 3. - С. 43-50.

7. Слюсаренко О.І. Стан та оснащення Сил спеціальних операцій Збройних Сил України колісними машинами / О.І. Слюсаренко // Військово-технічний збірник. - 2018. - № 18. - С. 93-98.

8. Neville L. Special Operations Forces in Afghanistan (Elite) / L. Neville. - Oxford: Osprey Publishing, 2008. - 64 p.

9. Neville L. Special Operations Forces in Iraq / L. Neville. - Oxford: Osprey Publishing, 2011. - 64 p.

10. Neville L. Special Operations Patrol Vehicles: Afghanistan and Iraq / L. Neville. - Oxford: Osprey Publishing, 2011. - 48 p.

11. Neville L. Technicals: Non-Standard Tactical Vehicles from the Great Toyota War to modern Special Forces $/$ L. Neville. - Oxford: Osprey Publishing, 2018. - 48 p.

12. Загарин Д.А. Предложения по созданию многоцелевых грузовых автомобилей нового поколения / Д.А. Загарин, М.А. Козловская, А.С. Шкель // Журнал Автомобильных Инженеров. - 2016. - № 2(97). - С. 18-25.

13. Купріненко О.М. Бойові броньовані машини. Концептуальні основи проектування: монографія / О.М. Купріненко. - Львів: НАСВ, 2017. - 198 с.

14. Ярушкина Н.Г. Интеллектуальный анализ временных рядов / Н.Г. Ярушкина, Т.В. Афанасьева, И.Г Перфильева. - Ульяновск: УлГТУ, 2010. - 320 с.

15. Ротштейн А.П. Интеллектуальные технологии идентификации: нечеткая логика, генетические алгоритмы, нейронные сети / А.П. Ротштейн // Винница: УНІВЕРСУМ-Вінниця, 1999. - 320 с.

16. Голуб В.А. Класифікація бойових колісних машин методами кластерного аналізу / В.А. Голуб // Системи озброєння і військова техніка. - 2011. - № 2(26). - С. 37-41.

17. Мандель И.Д. Кластерный анализ / И.Д. Мандель. - М.: - Финансы и статистика, 1988. - 176 с.

18. Вятченин Д.А. Нечеткие методы автоматической классификации: монография / Д.А. Вятченин. - Минск: Технопринт, 2004. - 219 с.

19. Дюран П. Кластерный анализ / П. Дюран, П. Оделл. - М.: Статистика, 1977. - 128 с.

20. Популярное введение в программу STATISTICA / В.П. Боровиков. - М.: Финансы и статистика, 1989. -215 с.

\section{References}

1. Vorobiov, H.P. (2014), "Rozvytok form i sposobiv zastosuvannia Zbroinykh Syl Ukrainy" [Development of forms and methods of use of the Armed Forces of Ukraine], Science and Defense, No. 1, pp. 27-30.

2. The Decree of the President of Ukraine (2015), "Pro novu redaktsiiu Voiennoi doktryny Ukrainy" № 555/2015 vid 24 veresnia 2015" [On the new version of the military doctrine of Ukraine No. 555/2015 dated 24.09.2015], available at: www.zakon.rada.gov.ua/laws/show/555/2015 (accessed 10 December 2019).

3. Chepkov, I.B. and Nor, P.I. (2014), "Zahalni tendentsii rozvytku ozbroiennia ta viiskovoi tekhniky" [General trends in the development of weapons and military equipment], Weapons and Military Equipment, No. 1, pp. 4-13. https:// doi.org/10.34169/2414-0651.2014.1(1).4-13.

4. Sliusarenko, A.V. (2017), "Dosvid stvorennia ta struktura syl spetsialnykh operatsii providnykh krain svitu” [Experience of creation and structure of Special Operations forces of the leading countries of the world], Military Scientific Journal, No. 29, pp. 170-181. https://doi.org/10.33577/2313-5603.29.2018.170-181.

5. Lutsenko, A.S. (2010), “Analiz dosvidu stvorennia, tendentsii rozvytku ta osoblyvostei pidhotovky syl spetsialnykh operatsii" [Analysis of experience of creation, tendencies of development and features of preparation of Special Operations forces], Systems of Arms and Military Equipment, No. 1(21), pp. 27-30.

6. Chepkov, I.B., Borokhvostov, I.V., Borokhvostov, V.K. and Rusevych, A.O. (2014), "Problemy tekhnichnoho osnashchennia Zbroinykh Syl Ukrainy ta shliakhy yikh rozviazannia v suchasnykh umovakh" [Problems of technical equipment of the Armed Forces of Ukraine and ways of their solution in modern conditions], Science and Defense, No. 3, pp. 43-50.

7. Sliusarenko, O. (2018), "Stan ta osnashchennya Syl spetsialnykh operatsiy Zbroynykh Syl Ukrayiny kolisnymy mashynamy" [Condition and equipment of Special Operations Forces of the Armed Forces of Ukraine by wheeled vehicles], Military Technical Collection, No. 18, pp.93-98.

8. Neville, L. (2008), Special Operations Forces in Afghanistan (Elite), Osprey Publishing, Oxford, 64 p.

9. Neville, L. (2011), Special Operations Forces in Iraq, Osprey Publishing, Oxford, 64 p.

10. Neville, L. (2011), Special Operations Patrol Vehicles: Afghanistan and Iraq, Osprey Publishing, Oxford, 48 p.

11. Neville, L. (2018), Technicals: Non-Standard Tactical Vehicles from the Great Toyota War to modern Special Forces, Osprey Publishing, Oxford, 48 p. 
12. Holub, V.A., Chepkov, I.B., Kuprinenko, O.M., Chechenkova, O.L. and Hulyayev, A.V. (2011), "Klasyfikatsiya boyovykh kolisnykh mashyn metodamy nechitkoho klasternoho analizu" [Classification of combat vehicles by indistinct cluster analysis methods], Automotive Engineers Magazine, No. 20, pp. 201-209.

13. Kuprinenko, O.M. (2017), "Boiovi bronovani mashyny. Kontseptualni osnovy proektuvannia" [Combat armored vehicles. Conceptual bases of designing], NASV, Lviv, $198 \mathrm{p.}$

14. Yarushkyna, N.H., Afanaseva, T.V. and Perfyleva, Y.H. (2010), "Yntellektualnyi analyz vremennykh riadov" [Intellectual analysis of time series], ULHTU, Ulianovsk, $320 \mathrm{p}$.

15. Rotshtein, A.P. (1999), "Yntellektualnye tekhnolohyy ydentyfykatsyy: nechetkaia lohyka, henetycheskye alhorytmy, neironnye sety" [Intellectual technologies in identification: fuzzy sets, genetic algorithm, neural nets], UNIVERSUM-Vinnytsia, Vynnytsa, $320 \mathrm{p}$.

16. Holub, V.A. (2011), "Klasyfikatsiia boiovykh kolisnykh mashyn metodamy klasternoho analizu" [Classification of combat wheeled vehicles by cluster analysis methods], Systems of Arms and Military Equipment, No. 2(26), pp. 37-41.

17. Mandel, I.D. (1988), "Klasternyi analiz" [Cluster analysis], Finansy i statistika, Moscow, 176 p.

18. Viatchenin, D.A. (2004), "Nechetkye metody avtomatycheskoi klassyfykatsyy" [Fuzzy methods of automatic classification], Tehnoprin, Minsk, $219 \mathrm{p}$.

19. Diuran, P. and Odell, P. (1977), "Klasternyi analiz" [Cluster analysis], Statyistyika, Moscow, 128 p.

20. Borovykov, V.P. (1989), "Populiarnoe vvedenye v prohrammu STATISTICA" [A popular introduction to the "Statistica” program], Fyinansy i statystyka, Moscow, $215 \mathrm{p}$.

\section{Відомості про авторів:}

\section{Слюсаренко Олександр Іванович}

ад’юнкт Національної академії

Сухопутних військ ім. гетьмана П. Сагайдачного,

Львів, Україна

https://orcid.org/0000-0003-2566-5693

\section{Купріненко Олександр Миколайович}

доктор технічних наук старший науковий співробітник начальник кафедри Національної академії Сухопутних військ ім. гетьмана П.Сагайдачного, Львів, Україна

https://orcid.org/0000-0003-2566-5693

\section{Кузнецов Свген Володимирович} слухач національного університету оборони України ім. Івана Черняховського, Київ, Україна https://orcid.org/0000-0003-0392-6194

\section{Information about the authors:}

Oleksandr Sliusarenko

Doctoral Student of Hetman Petro Sahaidachnyi

National Army Academy,

Lviv, Ukraine,

https://orcid.org/0000-0003-2566-5693

\author{
Oleksandr Kuprinenko \\ Doctor of Technical Sciences Senior Research \\ Chief of Department of Hetman Petro Sahaidachnyi \\ National Army Academy, \\ Lviv, Ukraine, \\ https://orcid.org/0000-0001-6692-0959
}

\author{
Yevhen Kuznetsov \\ Postgraduate Student \\ of Ivan Cherniakhovskyi \\ National Defence University of Ukraine \\ Kyiv, Ukraine, \\ https://orcid.org/0000-0003-0392-6194
}

\title{
ОПРЕДЕЛЕНИЕ ГРУПП КОЛЕСНЫХ МАШИН СИЛ СПЕЦИАЛЬНЫХ ОПЕРАЦИЙ ВООРУЖЕННЫХ СИЛ УКРАИНЫ ПО ФУНКЦИОНАЛЬНЫМ ПОКАЗАТЕЛЯМ МЕТОДАМИ КЛАСТЕРНОГО АНАЛИЗА ЗАДАЧ
}

\author{
А.И. Слюсаренко, А.Н. Куприненко, Е.В. Кузнецов
}

В статье проведен анализ существующих подходов формирования парков колесных машин вооруженных сил ведущзих стран и основных мировых тенденций их развития. Определены основные функциональные показатели колесных машин, которые влияют на полноту и качество выполнения задач подразделениями Сил спеииальных операций Вооруженных Сил Украины. Рассмотрены проблемы разработки номенклатуры колесных машин для нужд Сил специальных операций Вооруженных Сил Украины в соответствии со спецификой возложенных на них задач. За результатами проведенного анализа совокупности задач, которые возлагаются на Силь специальных операций Вооруженных Сил Украины, определены основные действия подразделений Сил специальных операчий и требования к функииональнымм показателей колесных машин. Широкое разнообразие вариантов применения подразделений Сил специильных операций и требований к колесным машинам обусловливает необходимость систематизачии задач по функииональным показателям колесных машин. Кластерный анализ значений оиенок экспертов в области применения подразделений Сил спеииальных операций Вооруженных Сил Украины позволил определить классы колесных машин, необходимых для решения полного спектра задач Сил специальных операций Вооруженных Сил Украины.

Ключевые слова: силь специальных операций, задачи, колесные машины, кластерный анализ, номенклатура, функциональные показатели. 


\section{DETERMINATION OF GROUPS OF WHEELED VEHICLES FOR SPECIAL OPERATIONS OF THE ARMED FORCES OF UKRAINE BY FUNCTIONAL INDICATORS BY METHODS OF CLUSTERAL TASK ANALYSIS}

O. Sliusarenko, O. Kuprinenko, Y. Kuznetsov

The need to counter new threats and challenges has led to the emergence in the armed forces of many leading countries of a new separate component - special operations forces that are able to adequately respond to new challenges and threats to national and international security, not only in wartime but also in peacetime, as abroad and in their own territory. In such circumstances, they should be equipped with modern high-tech models of military equipment that are as appropriate as possible to the solution of a wide range of special tasks and are not peculiar to other types (armies) of troops (forces), special forces of the Armed Forces of Ukraine. The necessity of providing the Special Operations Forces of the Armed Forces of Ukraine with wheeled vehicles, their worldwide wide nomenclature and the specificity of the tasks assigned to the Special Operations Forces on the one hand, and the limited economic capabilities of Ukraine, on the other, make it possible to state that for the Special Operations Forces of the Armed Forces of Ukraine it is advisable to have a rational composition of the nomenclature of wheeled vehicles, systematized and unified in terms of functional and structural features, values of parameters that provide promising demand Special Operations Forces. The article analyzes the existing approaches of formation of wheeled car parks of the armed forces of the leading countries and the main world tendencies of their development. There were determined the main functional indicators of the wheeled machines, which influence the completeness and quality of the tasks of the Special Operations Forces of the Armed Forces of Ukraine. The problems of designing wheel nomenclature for the needs of the Special Operations Forces of the Armed Forces of Ukraine, in accordance with the specifics of the tasks assigned to them, are considered. The results of the analysis of the set of tasks that are assigned to the Special Operations Forces of the Armed Forces of Ukraine identified the main actions of the units of the Special Operations Forces and requirements for functional indicators of wheeled vehicles. The wide variety of applications of the Special Operations Forces units and requirements for wheeled vehicles necessitates the systematization of tasks according to the functional parameters of wheeled vehicles. The cluster analysis of the values of the experts' assessments in the field of application of the Special Operations Forces units of the Armed Forces of Ukraine made it possible to determine the classes of wheeled vehicles needed to solve the full range of tasks of the Special Operations Forces of the Armed Forces of Ukraine.

Keywords: Special Operations Forces, tasks, wheeled vehicles, the cluster analysis, nomenclature, functional parameters. 